\title{
An Enhanced cAMP Pathway Is Responsible for the Colonic Hyper-Secretory Response to 5-HT in Acute Stress Rats
}

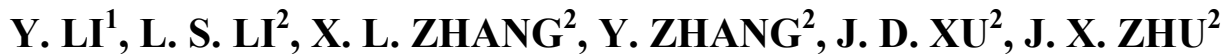 \\ ${ }^{1}$ Department of Immunology, Capital Medical University, Beijing, P. R. China, ${ }^{2}$ Department of \\ Physiology and Pathophysiology, Capital Medical University, Beijing, P. R. China
}

Received July 6, 2014

Accepted November 4, 2014

On-line December 22, 2014

\section{Summary}

5-hydroxytryptamine (5-HT) is involved in the stress-induced alteration of colonic functions, specifically motility and secretion, but its precise mechanisms of regulation remain unclear. In the present study, we have investigated the effects of $5-\mathrm{HT}$ on rat colonic mucosal secretion after acute water immersion restraint stress, as well as the underlying mechanism of this phenomenon, using short circuit current recording $\left(I_{\mathrm{SC}}\right)$, real-time polymerase chain reaction, Western blot analysis, and enzyme-linked immunosorbance assays. After $2 \mathrm{~h}$ of water immersion restraint stress, the baseline $I_{\mathrm{SC}}$ and 5 -HT-induced $I_{\mathrm{SC}}$ responses of the colonic mucosa were significantly increased. Pretreatment with selective $5-\mathrm{HT}_{4}$ receptor antagonist, SB204070, inhibited the 5-HT-induced colonic $I_{\text {SC }}$ response by $96 \%$ in normal rats and $91.2 \%$ in acute-stress rats. However, pretreatment with the selective antagonist of $5-\mathrm{HT}_{3}$ receptor, MDL72222 or Y-25130, had no obvious effect on $5-\mathrm{HT}$-induced $I_{\mathrm{SC}}$ responses under either set of conditions. Total protein expression of both the mucosal $5-\mathrm{HT}_{3}$ receptors and the $5-\mathrm{HT}_{4}$ receptors underwent no significant changes following acute stress. Both colonic basal cAMP levels and foskolin-induced $I_{\text {SC }}$ responses were significantly enhanced in acute stress rats. 5-HT significantly enhanced the intracellular cAMP level via $5-\mathrm{HT}_{4}$ receptors in the colonic mucosa from both control and stressed animals, and 5-HT-induced cAMP increase in stressed rats was not more than that in control rats. Taken together, the present results indicate that acute water immersion restraint stress enhances colonic secretory responses to $5-\mathrm{HT}$ in rats, a process in which increased cellular cAMP accumulation is involved.

\section{Key words}

5-hydroxytryptamine $\bullet$ Colon $\bullet$ Ion transport $\bullet$ cAMP $\bullet$ Stress

\section{Corresponding authors}

L. S. Li, Department of Physiology and Pathophysiology, Capital Medical University, Beijing, 100069, P. R. China. Fax: (+86)-1083911494. E-mail: Ilslls1995@163.com and J. D. Xu, Department of Physiology and Pathophysiology, Capital Medical University, Beijing, 100069, P. R. China. Fax: (+86)-10-83911494. E-mail: xu_jdd@ccmu.edu.cn

\section{Introduction}

5-hydroxytryptamine (5-HT, serotonin) is a well-known neurotransmitter in central nervous system, but most of 5-HT is from intestinal enterochromaffin (EC) cells and very small part of 5-HT is from enteric nervous system. Enteric 5-HT plays an important role in the gastrointestinal tract as a bioactive mediator or signal molecular by neurotransmitter and paracrine fashions. 5-HT exerts significant effects on regulating sensory, motor and secretory functions of the digestive system through interacting with the different receptor subtypes $\left(5-\mathrm{HT}_{1}-5-\mathrm{HT}_{7}\right)($ Gershon and Tack 2007). It is a potent paracrine secretagogue acting on the intestines of all studied species, including humans (Hansen and Witte 2008). Studies show that 5-HT stimulates intestinal secretion primarily through the $5-\mathrm{HT}_{3}$ receptor and $5-\mathrm{HT}_{4}$ receptor (Nagakura et al. 1997, Ning et al. 2004, Yang et al. 2010). 5- $\mathrm{HT}_{3}$ receptors belong to the ion-channellinked receptor superfamily, whereas $5-\mathrm{HT}_{4}$ receptors belong to $G$ protein-coupled receptor superfamily that stimulate cAMP production in response to 5-HT (Gerald et al. 1995).

Various types of psychological and physical 
stressors have a significant impact on several components of intestinal mucosal function, which is thought to contribute to symptoms in chronic inflammatory diseases and functional disorders of the gastrointestinal tract (Kim et al. 2010, Konturek et al. 2011). In vivo and in vitro studies suggest that 5 -HT is related to stress-induced alterations of colonic secretion, and peripheral $5-\mathrm{HT}_{3}$ and 5- $\mathrm{HT}_{4}$ receptors are involved in this process (Kiso et al. 1997, Goldhill et al. 1998, Hirata et al. 2008, Li et al. 2011). Furthermore, in the clinical practice, both $5-\mathrm{HT}_{3}$ receptor (Fujita et al. 2005) and 5- $\mathrm{HT}_{4}$ receptor agonists (Camilleri et al. 2008) have proved effective in treating constipation. However, the precise mechanisms by which 5-HT regulates colonic mucosal secretion during stress remain unclear. The aim of the present study is to investigate the alterations of 5-HT-induced rat colonic ion transport following acute stress, and to determine the underlying mechanisms of this phenomenon.

\section{Animals and Methods}

Animals and water immersion restraint stress models

The animal use protocol, which is based on NIH guidelines, was approved by the Animal Care and Use Committee of Capital Medical University. Adult male Sprague-Dawley rats (Laboratory Animal Services Center, Capital Medical University) ranging 200-300 g had free access to standard rodent laboratory food and water until the day of the experiments. The rats were randomly divided into the following two groups: control and water-immersion restraint stress (WIRS). The WIRS group rats, were tied to a wooden board, and their entire bodies, except for their heads, were immersed vertically to the level of the xiphoid process in a water bath maintained at $19 \pm 1^{\circ} \mathrm{C}$ for $2 \mathrm{~h}$ as previously described ( $\mathrm{Li}$ et al. 2006, 2011). Animals were conscious during the stress procedure. At the end of the experimental period, the animals were euthanized by cervical dislocation.

\section{Colonic mucosa preparation}

The distal colon was removed and defined as an approximately $7 \mathrm{~cm}$-long segments proximal to the lymph node of anus. As previous studies (Yang et al. 2006) demonstrated that different segments of the distal colon have diverse physiological properties, the distal colon was divided into four segments, which were termed DC1 (adjacent to the lymph node), DC2, DC3 and DC4. DC3 and DC4 were chosen for the study, due to their consistent and similar responses to 5-HT. Each tissue was cut along the mesenteric border into a flat sheet and flushed with ice-cold oxygenated Krebs-Henseleit solution (K-HS) containing the following ingredients: $117 \mathrm{mM} \mathrm{NaCl}, 4.7 \mathrm{mM} \mathrm{KCl}, 1.2 \mathrm{mM} \mathrm{MgCl} \cdot 6 \mathrm{H}_{2} \mathrm{O}$, $1.2 \mathrm{mM} \mathrm{NaH} \mathrm{PO}_{4}, 25 \mathrm{mM} \quad \mathrm{NaHCO}_{3}$, and $2.5 \mathrm{mM}$ $\mathrm{CaCl}_{2} \cdot 2 \mathrm{H}_{2} \mathrm{O}$. Additionally, as described in our previous study ( $\mathrm{Li}$ et al. 2011), endogenous prostaglandins are released during tissue preparation, and the cyclooxygenase (COX) pathway plays a major role in the mediation of the secretory response to exogenous 5 -HT in vitro, indomethacin $(10 \mu \mathrm{M})$, a COX inhibitor, was routinely added to the K-HS. The tissue was pinned flat with the mucosal side facing up in a petri-dish containing ice-cold oxygenated K-HS. The colonic mucosa-only preparations were obtained using dissecting forceps under a dissecting microscope.

\section{Short circuit current measurement}

Short circuit current $\left(I_{\mathrm{SC}}\right)$ was measured in vitro in Ussing chambers. A flat sheet of the colonic mucosaonly preparation was mounted between two halves of a modified Ussing chamber, in which the total crosssectional area was $0.5 \mathrm{~cm}^{2}$. The basal and apical surfaces of the tissue were bathed in $5 \mathrm{ml}$ of K-HS maintained at $37^{\circ} \mathrm{C}$ via by recirculation from a reservoir during the experiments. The K-HS was bubbled with $95 \% \mathrm{O}_{2}$ and $5 \% \mathrm{CO}_{2}$ to maintain the $\mathrm{pH}$ of the solution at 7.4. The trans-epithelial potential difference of each preparation of colonic mucosa was measured with $\mathrm{Ag} / \mathrm{AgCl}$ reference electrodes (Physiologic Instruments, San Diego, CA, USA; P2020S) connected to a preamplifier that was, in turn, connected to a voltage-clamp amplifier (Physiologic Instruments, San Diego, CA, USA; VCC MC6). The tissue was continuously voltage-clamped to a zero potential difference by the application of external current, with compensation for fluid resistance. The tissues were allowed to rest for approximately $30 \mathrm{~min}$ to stabilize. Drugs were added directly to either the basolateral side of the epithelial sheets. Responses were continuously recorded by a computer. The transepithelial resistance $\left(\Omega \mathrm{cm}^{2}\right)$ was measured by altering the membrane potential in a stepwise fashion $(-0.1 \mathrm{mV})$ and applying Ohm's law. The baseline value of the electrical parameters was determined as the mean over the $3 \mathrm{~min}$ immediately prior to drug administration. The change in $I_{\mathrm{SC}}$ response $\left(\Delta I_{\mathrm{SC}}\right)$ was calculated on the basis of the values before and after stimulation and was normalized as current per unit area of epithelium $\left(\mu \mathrm{A} \cdot \mathrm{cm}^{-2}\right)$, which allowed the area under the curve for $15 \mathrm{~min}$ to be 
calculated $(\mu \mathrm{A} \cdot \min )$. A positive $I_{\mathrm{SC}}$ corresponded to the net eletrogenic anion secretion (such as $\mathrm{Cl}^{-}$) or cation absorption (such as $\mathrm{Na}^{+}$).

\section{Real time RT-PCR}

Total RNA from the colonic mucosa preparations was extracted using TRIzol Reagent (Invitrogen, Carlsbad, CA, USA) according to the protocol of the manufacturer. The first strand of cDNA was synthesized following the protocol of the superscript first-strand synthesis system for RT-PCR (Invitrogen). Transcripts encoding $5-\mathrm{HT}_{3}$ receptors, 5- $\mathrm{HT}_{4}$ receptors and $\beta$-actin in samples of WIRS and control rat colonic mucosa were comparatively quantified by real time PCR with the Brilliant SYBR Green QPCR Master Mix kit (Stratagene, La Jolla, CA, USA), using a Light Cycler instrument (Stratagene). Expression of $\beta$-actin was used as an internal control for normalization. Amplifications were performed in a final volume of $20 \mu \mathrm{l}$ of reaction mixture according to the manufacturer's instructions. The primers were used at a final concentration of $0.2 \mu \mathrm{M}$, and $0.3 \mu \mathrm{l}$ of cDNA prepared from tissue were added to the mixture. Data were analyzed with MxPro QPCR software (version 3.0, Mx3000P system, Stratagene). Primer sequences used for amplifications were as follows: $\beta$-actin, forward: 5'-TTC AAC ACC CCA GCC ATG T-3', reverse: 5'-GTG GTA CGA CCA GAG GCA TAC A-3'; 5- $\mathrm{HT}_{3}$ receptor, forward: 5'-TGC ATA CCA TCC AGG ACA TCA-3', reverse: 5'-CTC TTG TCC GAC CTC ACT TCT TC-3'; 5- $\mathrm{HT}_{4}$ receptor, forward: 5'-GCT GGG TCA TTC CCA TGT TT-3', reverse: 5'-CAA CTA TGC CGA TGT TGT TCC A-3'.

\section{Western blotting}

Parts of the colonic mucosa $(0.1 \sim 0.2 \mathrm{~g})$ were harvested from control and WIRS rats prior to short circuit current experiments. All samples were washed with cold phosphate-buffered saline (PBS) and homogenized in $300 \mu \mathrm{l}$ of cold lysis buffer, $\mathrm{pH} 7.5$, containing Nonidet P-40 (1\%), Tris- $\mathrm{HCl}$ (10 mM, pH 8.0), $\mathrm{NaCl}(150 \mathrm{mM}), \operatorname{SDS}(0.1 \%)$, EDTA (1 mM), leupeptin $(5 \mu \mathrm{g} / \mathrm{ml})$, aprotinin $(5 \mu \mathrm{g} / \mathrm{ml})$, PMSF $(1 \mathrm{mM})$, deoxycholic acid $(0.5 \%)$ and sodium orthovanadate $(1 \mathrm{mM})$, all of which were purchased from the Sigma Company. Total tissue homogenates were sonicated to dissolve them completely and then centrifuged at $12,000 \mathrm{rpm}$ for $30 \mathrm{~min}$ at $4{ }^{\circ} \mathrm{C}$ to separate the membranecontaining fraction (pellet) from the cytosol. The supernatant was collected, and its protein level was quantified by the BCA assay according to the manufacturer's protocol (Thermo, Rockford, IL, USA). Proteins $(100 \mu \mathrm{g})$ were separated by $10 \%$ SDSpolyacrylamide gel electrophoresis. Following electrophoresis and the transfer of proteins onto the nitrocellulose membrane (Millipore, Billerica, MA, USA), the membrane was blocked in TBST (20 mM Tris-HCl, pH 7.5, 150 mM NaCl, $0.05 \%$ v/v Tween-20) containing $10 \%$ nonfat milk for $1 \mathrm{~h}$ at room temperature. The membrane was then incubated with primary polyclonal antibodies to the $5-\mathrm{HT}_{3}$ receptor (Santa Cruz/sc-28958, diluted 1:400), 5- $\mathrm{HT}_{4}$ receptor (Novus/NBP1-19627, diluted 1:600), GAPDH (Sigma/G9545, diluted 1:10000) or Actin (Sigma/A 5060, diluted 1:10000) overnight at $4{ }^{\circ} \mathrm{C}$. After being washed 3 times in TBST, for $10 \mathrm{~min}$ each wash, the membrane was incubated with the appropriate secondary antibodies (goat anti-rabbit IgG, Rockland/16747, diluted 1:10000) for $1 \mathrm{~h}$ at room temperature, followed by washing as performed previously. The protein bands were visualized via scanning by Odyssey Infrared Imager (LI-COR, NE, USA), and analyzed by Odyssey software (version 1.2).

\section{cAMP measurement}

Rat colonic mucosa samples (about $150 \mathrm{mg}$ ) were incubated in K-HS solution for 30 min for equilibration, and all samples were pretreated with indomethacin $(10 \mu \mathrm{M})$, TTX $(1 \mu \mathrm{M})$. The samples were pretreated with vehicle (saline), 5- $\mathrm{HT}_{4}$ receptor antagonists (SB204070, $1 \mu \mathrm{M}$ ) for $5 \mathrm{~min}$ before adding 5-HT (10 $\mu \mathrm{M}, 20 \mathrm{~min})$. All colonic mucosa-only samples from the WIRS and control rats were frozen in liquid nitrogen immediately and ground into a fine powder under liquid nitrogen by a stainless steel mortar. After the liquid nitrogen evaporated, the frozen tissues were weighed and homogenized in 10 volumes of $0.1 \mathrm{M} \mathrm{HCl}$ before being centrifuged at $600 \times \mathrm{g}$ at room temperature for $5 \mathrm{~min}$. The supernatant was subsequently collected for cAMP measurement. Intracellular levels of cAMP were determined using the Enzyme Immunoassay direct cyclic AMP kit according to the manufacturer's instructions (Sigma-Aldrich, St. Louis, MO, USA). The optical density (OD), which was inversely proportional to the concentration of cAMP in both the standards and the samples, was read at $405 \mathrm{~nm}$ on a microplate reader (Bio-Rad).

\section{Drugs}

5-hydroxytryptamine (5-HT), 3-tropanyl-3, 5-dichlorobenzoate (MDL72222), (1-Butyl-4-piperidinyl) 
methyl-8-amino-7-chloro-1,

4-benzodioxane-5-

carboxylate hydrochloride (SB204070), GR113808, indomethacin, and tetrodotoxin (TTX) were obtained from Sigma Chemical Company (St. Louis, MO, USA). Y-25130 hydrochloride (Y-25130) were obtained from Tocris bioscience (Tocris Cookson Ltd, UK). Drug concentrations were chosen based on previous studies. Stock solutions of indomethacin and MDL72222 were dissolved in dimethyl sulphoxide (DMSO), and the final DMSO concentrations never exceeded $0.1 \%(\mathrm{v} / \mathrm{v})$. The other drugs were dissolved in aqueous stock solution.

\section{Statistical analysis}

The values are presented as means \pm SEM (standard error of mean): $\mathrm{n}$ refers to the number of rats or the number of pairs used. The statistics and graphs were generated using GraphPad Prism, version 5.0 (GraphPad Software Inc., San Diego, CA, USA). Statistical analysis was conducted using Student's paired or unpaired t-test. $P$ values less than 0.05 denoted a statistically significant difference.
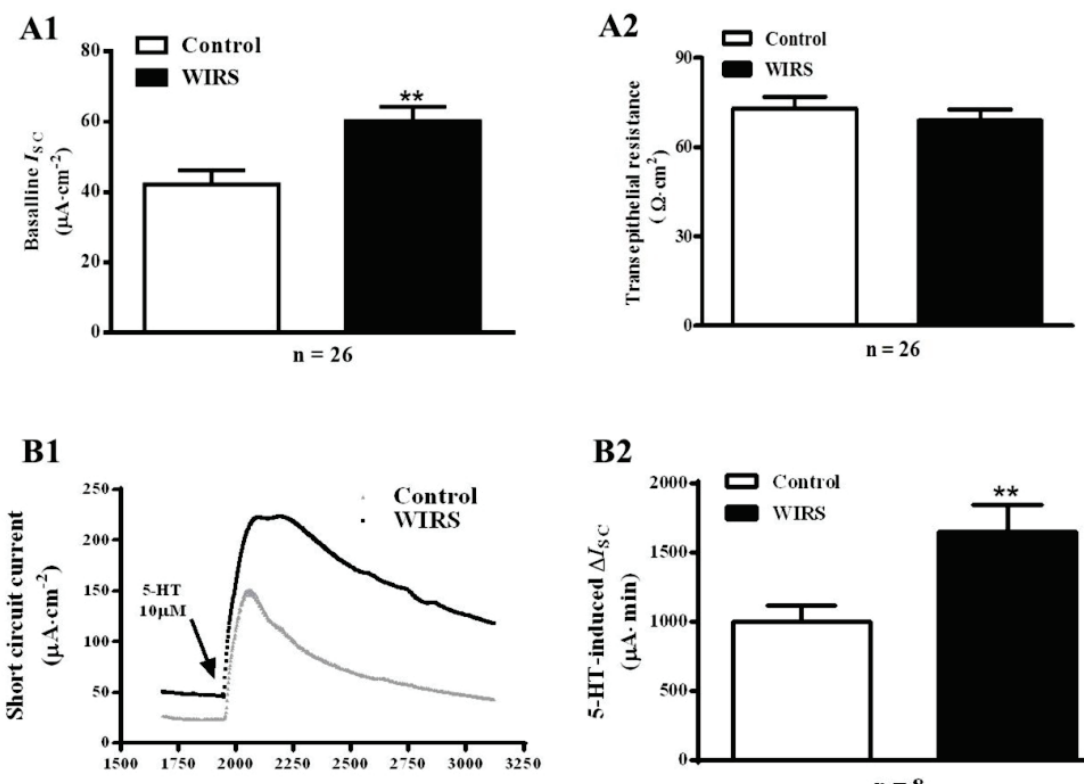

B2

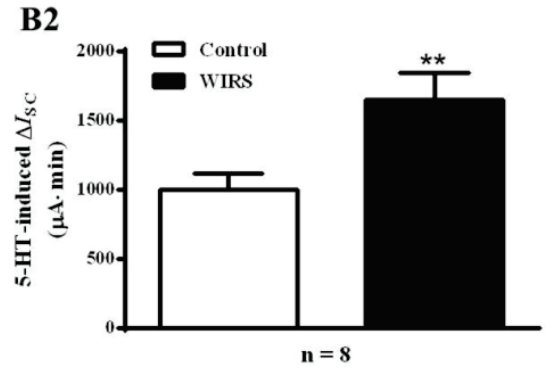

Fig. 1. Basic characteristics of electrophysiology and 5 -HT-induced $\Delta I_{\mathrm{SC}}$ in the distal colonic mucosa of control and WIRS rats. (A1) Baseline $I_{\text {sc. }}$ (A2) Transepithelial resistance. (B1) Representative $I_{\mathrm{SC}}$ recording with arrow indicates the application of $5-\mathrm{HT}(10 \mu \mathrm{M}$, basolateral side) to the colonic mucosa. (B2) Summary of 5 -HT-induced $\Delta I_{\mathrm{SC}}$ in colonic mucosa. Columns show the mean $\pm \mathrm{SEM}$, $* * \mathrm{P}<0.01$. WIRS, water immersion restraint stress; $I_{\mathrm{SC}}$, short circuit current.

\section{Results}

Alterations of basic characteristics of electrophysiology and 5-HT-induced ion transport in the rat distal colonic mucosa after water immersion restraint stress

After an equilibration time of about $30 \mathrm{~min}$, the mean basal $I_{\mathrm{SC}}$ and the transepithelial resistance (Rte) of the colonic epithelium were $42.2 \pm 4.0 \mu \mathrm{A} \cdot \mathrm{cm}^{-2}$ and $72.9 \pm 3.9 \Omega \cdot \mathrm{cm}^{2}$ in control rats, and $60.2 \pm 4.2 \mu \mathrm{A} \cdot \mathrm{cm}^{-2}$ and $68.8 \pm 3.7 \Omega \cdot \mathrm{cm}^{2}$ in rats exposed to $2 \mathrm{~h}$ of WIRS, respectively. The baseline $I_{\mathrm{SC}}$ in WIRS rats was significantly higher than that of the control rats, as it was $42.2 \pm 4.0 \mu \mathrm{A} \cdot \mathrm{cm}^{-2}$ for the control rats and $60.2 \pm 4.2$ $\mu \mathrm{A} \cdot \mathrm{cm}^{-2}$ for the WIRS rats $(\mathrm{n}=26, \mathrm{P}<0.01$, Fig. $1 \mathrm{~A} 1)$, but no significant difference in Rte was observed between the control and the WIRS rats $(\mathrm{n}=26, \mathrm{P}>0.05$, Fig. 1A2).

Based on our previous studies (Ning et al. 2004, Li et al. 2011), indomethacin $(10 \mu \mathrm{M})$ was routinely added to subsequent experiments to abolish the effects of endogenous prostaglandin, and the nerve conduction blocker, tetrodotoxin (TTX) $(1 \mu \mathrm{M})$, was later added to block any effects of residual nerve activity. Then, $10 \mu \mathrm{M}$ of 5-HT was added to the basolateral side of the tissue. The area under the $15 \mathrm{~min}$ period of $I_{\mathrm{SC}}$ recording was calculated to represent the total charge transfer per unit area for the given period.

The 5-HT-induced $\Delta I_{\mathrm{SC}}$ in colonic mucosa in WIRS rats $(1651.0 \pm 195.5 \mu \mathrm{A} \cdot \mathrm{min})$ was significantly higher than in control rats $(999.0 \pm 115.1 \mu \mathrm{A} \cdot \min )(\mathrm{n}=8$, $\mathrm{P}<0.01$, Fig. 1B1, B2).

Role of 5-HT $\mathrm{T}_{3}$ receptors in the enhanced 5-HT-induced ion transport in rat colonic mucosa under water immersion restraint stress condition

As shown in a previous study, 5-HT induces colonic ion transport by acting on $5-\mathrm{HT}_{3}$ and $5-\mathrm{HT}_{4}$ receptors, which are located on colonic epithelial cells (Budhoo and Kellum 1994, Glatzle et al. 2002, Hirata et 
al. 2008). We first tested the role of $5-\mathrm{HT}_{3}$ receptors in the setting of enhanced 5-HT-induced ion transport in WIRS rats. Highly seceletive $5-\mathrm{HT}_{3}$ receptor antagonists, MDL72222 $(10 \mu \mathrm{M})$ and Y-25130 $(5 \mu \mathrm{M})$, were chosen (Lee et al. 2005, Yang et al. 2010). Short circuit current results showed that pretreatment with MDL72222 $(10 \mu \mathrm{M})$ or Y-25130 $(5 \mu \mathrm{M})$ did not affect 5-HT-induced ion transport under either normal or WIRS conditions (n=5, Fig. 2A1,A2,A3,A4). Real time RT-PCR results showed that the mRNA expression of $5-\mathrm{HT}_{3}$ receptors in WIRS rats, was reduced by $43 \%$ compared with normal rats $(100 \%)(\mathrm{n}=4, \mathrm{P}<0.05$, Fig. $2 \mathrm{~B} 1)$. Western blot results showed no obvious alterations in the protein expression of $5-\mathrm{HT}_{3}$ receptors in WIRS rats compared with control rats ( $n=6, P>0.05$, Fig. $2 B 2)$.
A1

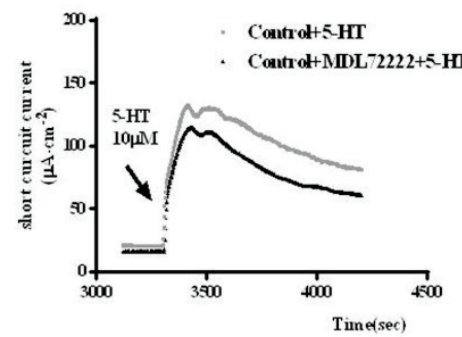

A3

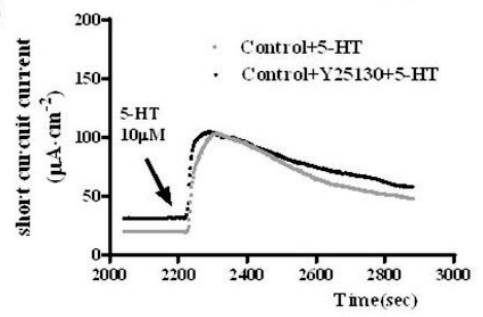

B1

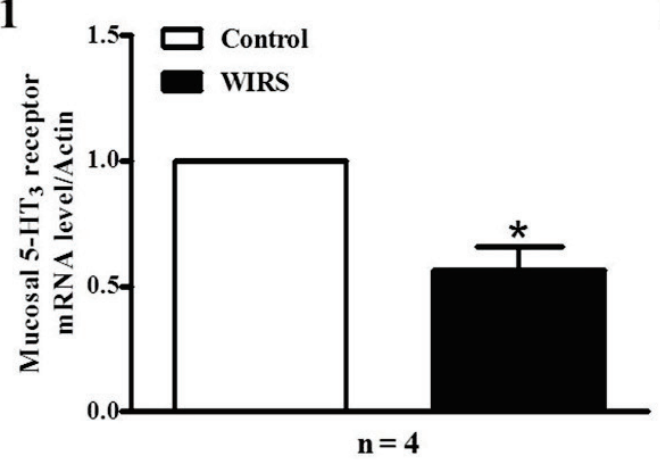

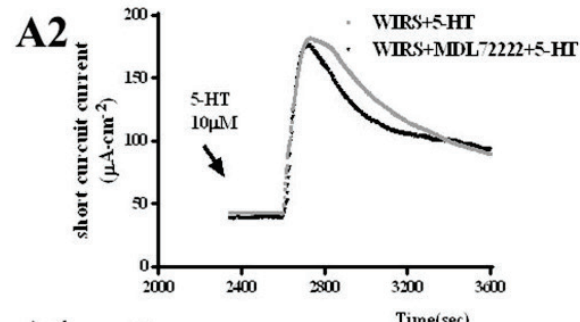

A4

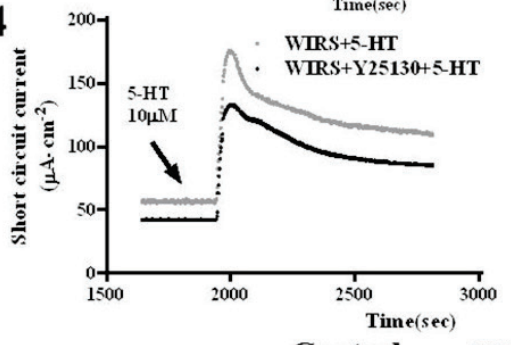

B2

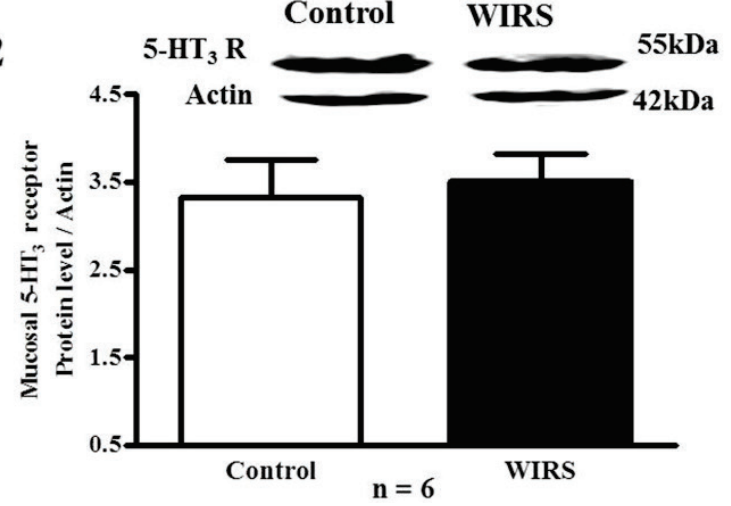

Fig. 2. Role of $5-\mathrm{HT}_{3}$ receptors in the enhanced $5-\mathrm{HT}$-induced $\Delta I_{\mathrm{SC}}$ in distal colonic mucosa of WIRS rats. Representative $I_{\mathrm{SC}}$ recording with arrows indicating the time for the basolateral application of $5-\mathrm{HT}(10 \mu \mathrm{M})$ to control $(\mathbf{A 1}, \mathbf{A} \mathbf{3})$ or WIRS $(\mathbf{A 2}, \mathbf{A 4})$ rats mucosa basolateral pretreated with MDL72222 $(10 \mu \mathrm{M}) \mathbf{( A 1 , A 2 )}$ or Y-25130 $(5 \mu \mathrm{M})(\mathbf{A 3}, \mathbf{A 4})$, respectively. The mRNA (B1) and protein (B2) levels of mucosal $5-\mathrm{HT}_{3}$ receptors. The difference in expression levels is reflected by variations in the $\mathrm{Y}$-axes. Columns show the mean $\pm \mathrm{SEM}, * \mathrm{P}<0.05$. WIRS, water immersion restraint stress; $I_{\mathrm{SC}}$, short circuit current.

Role of 5-HT 4 receptors in the enhanced 5-HT-induced ion transport in rat colonic mucosa under water immersion restraint stress condition

To determine the role of $5-\mathrm{HT}_{4}$ receptors in 5-HT-induced colonic ion transport in WIRS rats, the $5-\mathrm{HT}_{4}$ receptor specific antagonist, $1 \mu \mathrm{M}$ of SB204070 and $1 \mu \mathrm{M}$ of GR113808, was administered (Ning et al. 2004, Yuan et al. 2011). Short circuit current results indicated that pretreatment with SB204070 (1 $\mu \mathrm{M})$ inhibited 5-HT $(10 \mu \mathrm{M})$-induced $\Delta I_{\mathrm{SC}}$ by $96 \%$ in control rats $(\mathrm{n}=5, \mathrm{P}<0.01$, Fig. $3 \mathrm{~A} 1, \mathrm{~A} 3)$, and by $91.2 \%$ in WIRS rats $(\mathrm{n}=5, \mathrm{P}<0.01$, Fig. 3A2,A3). Pretreatment with another $5-\mathrm{HT}_{4}$ receptor specific antagonist, GR113808 $(1 \mu \mathrm{M})$, also almost totally inhibited 5-HT $(10 \mu \mathrm{M})$ induced $\Delta I_{\mathrm{SC}}$ in both group rats $(\mathrm{n}=4$, Fig. 3A4,A5). Real time RT-PCR results showed a $45 \%$ reduction in mRNA expression of $5-\mathrm{HT}_{4}$ receptors in WIRS rats compared with control rats $(n=6, P<0.001$, Fig. 3B1), but Western blot analysis revealed no significant alterations in protein expression of $5-\mathrm{HT}_{4}$ receptors in the colonic mucosa of WIRS rats $(n=6, P>0.05$, Fig. 3B2). 


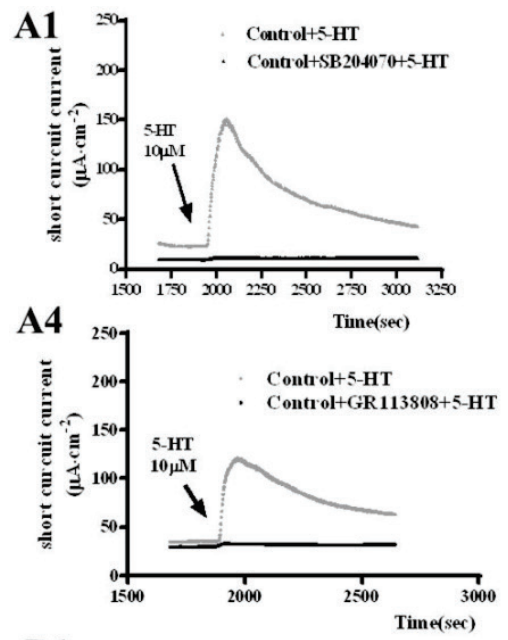

B1

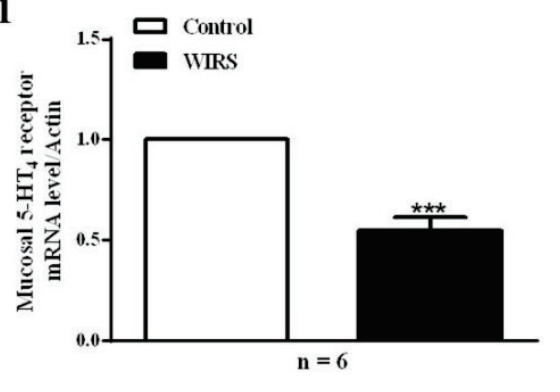

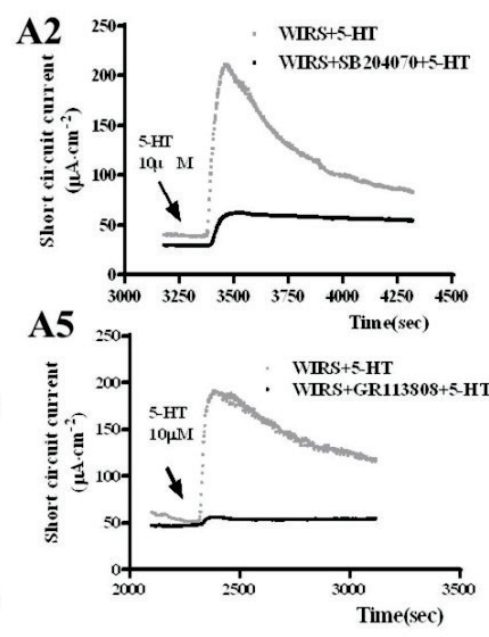

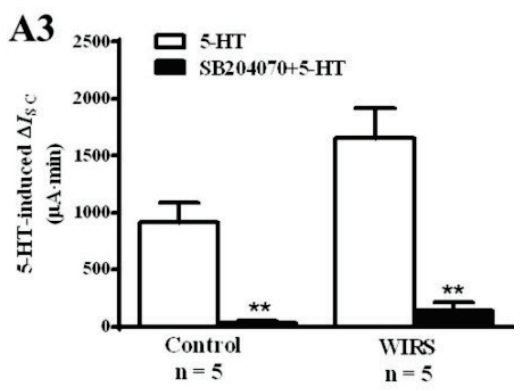

B2

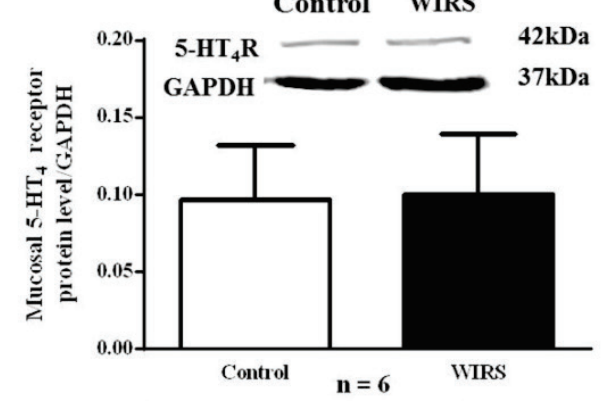

Fig. 3. Role of $5-\mathrm{HT}_{4}$ receptors in the enhanced $5-\mathrm{HT}$-induced $\Delta I_{\mathrm{SC}}$ in distal colonic mucosa of WIRS rats. Representative $I_{\mathrm{SC}}$ recording with arrows indicating the time for the basolateral application of $5-\mathrm{HT}(10 \mu \mathrm{M})$ to control $(\mathbf{A 1}, \mathbf{A 4})$ or WIRS $(\mathbf{A 2}, \mathbf{A 5})$ rats mucosa basolateral pretreated with SB204070 $(1 \mu \mathrm{M})(\mathbf{A 1}, \mathbf{A 2})$ or GR113808 $(1 \mu \mathrm{M})(\mathbf{A 4}, \mathbf{A 5})$, respectively. Summary of the effects of SB204070 on 5-HT-induced $\Delta I_{S C}$ (A3). The mRNA (B1) and protein (B2) levels of mucosal 5- $\mathrm{HT}_{4}$ receptors. The difference in expression levels is reflected by variations in the $\mathrm{Y}$-axes. Columns show the mean $\pm \mathrm{SEM}, * * \mathrm{P}<0.01, * * * \mathrm{P}<0.001$. WIRS, water immersion restraint stress; $I_{\mathrm{SC}}$, short circuit current.
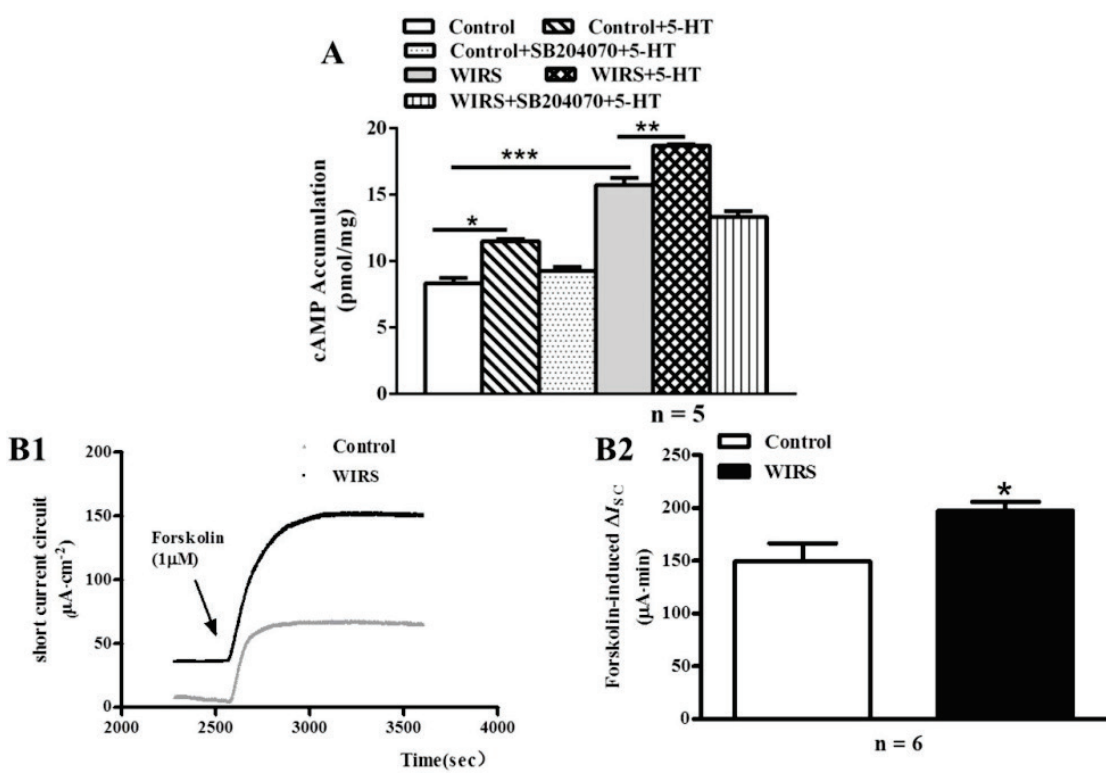

Fig. 4. Role of the cAMP pathway in the enhanced 5 -HT-induced $\Delta I_{S C}$ in distal colonic mucosa of WIRS rats. (A) Summary of the basal intracellular cAMP level and effects of $5-\mathrm{HT}_{4}$ receptor antagonists, SB204070 (1 $\mu \mathrm{M})$ on $5-\mathrm{HT}$ $(10 \mu \mathrm{M})$-stimulated intracellular cAMP production in the colonic mucosa preparations of control and WIRS rats. (B1) Representative $I_{\mathrm{SC}}$ recording with arrow indicates the application of forskolin ( $1 \mu \mathrm{M}$, basolateral side) to the mucosa. (B2) Summary of forskolin-induced $\Delta I_{\mathrm{sC}}$ in the colonic mucosa. Columns show the mean $\pm \mathrm{SEM}, \quad * \mathrm{P}<0.05, * * \mathrm{P}<0.01$, $* * * P<0.001$. WIRS, water immersion restraint stress; $I_{\mathrm{SC}}$, short circuit current.
Role of the cAMP pathway in enhanced 5-HT-induced ion transport in rat colonic mucosa under water immersion restraint stress condition

To measure the change in cellular cAMP levels, an ELISA was used. The results showed that the basal cAMP level in colonic epithelial cells of WIRS rats was
$11.5 \pm 0.15 \mathrm{pmol} / \mathrm{mg}$, which was significantly higher than that of control rats $(8.31 \pm 0.43 \mathrm{pmol} / \mathrm{mg})(\mathrm{n}=5, \mathrm{P}<0.001$, Fig. 4A). 5-HT increased intracellular cAMP level of colonic mucosa in control rats by $38.5 \%(\mathrm{n}=5, \mathrm{P}<0.05$, Fig. 4A) and in WIRS rats by $19.1 \%(\mathrm{n}=5, \mathrm{P}<0.01$, Fig. 4A). Pretreatment with $5-\mathrm{HT}_{4}$ receptor antagonist 
SB204070 $(1 \mu \mathrm{M})$ almost totally block 5-HT-induced increase in colonic intracellular cAMP of both control and WIRS rats ( $n=5$, Fig. 4A). Forskolin, an adenylate cyclase activator that does not require receptor mediation, was chosen to compare the effect of direct stimulation on colonic ion transport in both the WIRS and control groups, which imitate the effect of 5-HT. Basal addition of forskolin $(1 \mu \mathrm{M})$ stimulated an $I_{\mathrm{SC}}$ increase, $197.5 \pm 8.476 \mu \mathrm{A} \cdot \min$ in WIRS rats, which was much higher than that the $149.5 \pm 17.02 \mu \mathrm{A} \cdot \mathrm{min}$ increase observed in control rats ( $\mathrm{n}=6, \mathrm{P}<0.05$, Fig. 4B1,B2).

\section{Discussion}

Increasing evidence supports a prominent role of stress in the pathophysiology and clinical presentation of irritable bowel syndrome (IBS) and inflammatory bowel disease (IBD) (Chang 2011, Reber 2012). 5-HT acts as a mediator of stress-induced colonic dysfunction, the symptoms of which include an increase in stool excretion, diarrhea, and abdominal pain (Sanger et al. 2000, JulioPieper et al. 2012). Additionally, 5-HT has also been implicated in many gastrointestinal disorders, such as IBS and IBD (Manocha and Khan 2012). A combined blockade of $5-\mathrm{HT}_{3}$ and $5-\mathrm{HT}_{4}$ receptors can completely inhibits 5-HT-induced diarrhea in mice and rats (Nagakura et al. 1997). However, the mechanism of stress-induced alterations of 5-HT regulatory pathways in colonic ion transport is not clear. This study has investigated the mechanism underlying 5-HT-enhanced colonic ion transport under stressful conditions.

Stress induces hyper-secretion in the human intestine (Barclay and Turnberg 1987). Goldhill et al. (1998) have also reported that the in vitro response of the colonic epithelium to 5-HT is altered by prior wholebody stress, and have detected a bimodal effect. Mucosal tissue from approximately $50 \%$ of studied animals displayed a reduced responsiveness to 5-HT, which may be indicative of a reduction in receptor number, desensitization of receptors or induction of inhibitory pathways. In our previous studies, we have observed that activation of submucosal neural $5-\mathrm{HT}_{3}$ receptors elicited a somatostatin-dependent inhibition of ion secretion in rat colon (Yang et al. 2010). This neural 5- $\mathrm{HT}_{3}$ receptormediated somatostatin-dependent secretoinhibitory pathway is suppressed in the acute water-immersion restraint stressed rats (Li et al. 2011), which may contribute to the acute stress-induced increase in colonic secretion. However, we do not know whether non-neural
$5-\mathrm{HT}_{3}$ or $5-\mathrm{HT}_{4}$ receptors are involved in the colonic hyper-secretion in acute stress. Our results showed that the baseline $I_{\mathrm{SC}}$ of colonic mucosa tissues was significantly elevated in WIRS rats. And almost all colonic mucosa tissues from WIRS rats were hyperresponsive to 5-HT, which can be almost completely blocked by pretreatment with a $5-\mathrm{HT}_{4}$ receptor antagonist (SB204070 or GR113808). However, the protein level of $5-\mathrm{HT}_{4}$ receptors in stressed distal colonic mucosa of rats was not significant affected. This finding suggests that the increased ion transport induced by 5-HT is predominantly mediated by $5-\mathrm{HT}_{4}$ receptors in WIRS rats, but acute stress may have little impact on the number of $5-\mathrm{HT}_{4}$ receptors in colonic mucosa. Our results also showed that the mRNA level of both $5-\mathrm{HT}_{3}$ and $5-\mathrm{HT}_{4}$ receptors were significantly decreased in WIRS rats. This inconsistency between mRNA and protein might be the consequence of negative feedback regulation in rat colonic mucosa against the hyper-responsiveness to 5-HT. It has been also reported that the absence of mRNA-protein correlation for the investigated genes suggests that the relation between mRNA and protein is not strictly linear (de Sousa et al. 2009), and different regulation mechanisms (such as synthesis and degradation rates) acting on both the synthesized mRNA and protein affect the amount of the two molecules differentially.

We suppose that the increased 5-HT-induced $I_{\mathrm{SC}}$ response may be due to an upregulated second messenger system (cAMP) in stressed colonic epithelia, a finding supported by several pieces of evidence. First, previous investigations in our lab showed that 5-HT can elicits $\mathrm{Cl}^{-}$ and $\mathrm{HCO}_{3}^{-}$anion secretion and $\mathrm{Na}^{+}$absorption by acting directly on colonic epithelial cells via $5-\mathrm{HT}_{4}$ receptors, a process mediated by the cystic fibrosis transmembrane conductance regulator (CFTR) (Ning et al. 2004). Second, the $5-\mathrm{HT}_{4}$ receptor is a $\mathrm{G}$ protein-coupled receptor that stimulates cAMP production in response to serotonin, and CFTR functions as a cyclic adenosine 3',5'-monophosphate (cAMP)-regulated chloride channel, which is expressed at high levels in the crypts of adult colon (Crawford et al. 1991). Third, stress-related mediators (corticotropin releasing hormone, 5-HT, acetylcholine) (Larauche et al. 2009, Stengel and Tache 2009, Karantanos et al. 2010) directly act on their respective receptors during stress, and elevate the level of intracellular second messenger, such as $\mathrm{Ca}^{2+}$ and cAMP, which may induce more CFTR chloride channel activity (Prince et al. 1994) and result in a basal hyper-secretion 
condition within the stressed intestine.

To verify this hypothesis, cellular cAMP level was measured. The results showed that WIRS colonic mucosa had higher basal level of cAMP than the mucosa of control rats, which was consistent with our expectation. Since studies (Soderholm and Perdue 2001) have reported that stress could enhance baseline $\mathrm{Cl}^{-}$secretion of distal colon resulted in higher level of colonic baseline $I_{\mathrm{SC}}$, while $\mathrm{Cl}^{-}$secretion is mainly mediated by the cystic fibrosis transmembrane conductance regulator (CFTR), a cAMP-dependent $\mathrm{Cl}^{-}$channel. So, the higher level of cAMP might activate more CFTR and contribute to the elevated baseline $I_{\mathrm{SC}}$ in WIRS rats. 5-HT significantly increased the intracellular cAMP level via $5-\mathrm{HT}_{4}$ receptor in the colonic mucosa from both control and WIRS rats, but 5-HT-induced cAMP increase in WIRS rats was not more than that in control rats. Forskolin increased intracellular levels of cAMP by activating the enzyme adenylyl cyclase, which mimicked the effects of 5-HT on colonic ion transport by participating in the post-5- $\mathrm{HT}_{4}$ receptor signaling pathway. Short circuit current results also showed that the forskolin-induced $I_{\mathrm{SC}}$ response was consistent with the effects of 5-HT in stressed rats.

In conclusion, we have demonstrated that the ion transport of colonic mucosa induced by 5 -HT is increased in an animal model of acute stress via increases in intracellular cAMP, which may contribute to stressrelated hyper-secretion in humans. Whether the secretory responsiveness of the epithelium under acute stress condition undergoes a general change or is merely a specific phenomenon must be studied further by analyzing other secretagogues. This study may help us better understand the mechanisms underlying the gastrointestinal symptoms and discomfort associated with stress.

\section{Conflict of Interest}

There is no conflict of interest.

\section{Acknowledgements}

This study was financially supported by grants from the National Natural Science Foundation of China (31300954, 81270443, and 81370482), IDHT20140514, and the Science Foundation of Capital Medical University (2013ZR02).

\section{References}

BARCLAY GR, TURNBERG LA: Effect of psychological stress on salt and water transport in the human jejunum. Gastroenterology 93: 91-97, 1987.

BUDHOO MR, KELLUM JM: Evidence for a 5-HT4 receptor pathway mediating chloride secretion in the rat distal colon. J Surg Res 57: 44-48, 1994.

CAMILLERI M, KERSTENS R, RYKX A, VANDEPLASSCHE L: A placebo-controlled trial of prucalopride for severe chronic constipation. N Engl J Med 358: 2344-2354, 2008.

CHANG L: The role of stress on physiologic responses and clinical symptoms in irritable bowel syndrome. Gastroenterology 140: 761-765, 2011.

CRAWFORD I, MALONEY PC, ZEITLIN PL, GUGGINO WB, HYDE SC, TURLEY H, GATTER KC, HARRIS A, HIGGINS CF: Immunocytochemical localization of the cystic fibrosis gene product CFTR. Proc Natl Acad Sci USA 88: 9262-9266, 1991.

DE SOUSA AR, PENALVA LO, MARCOTTE EM, VOGEL C: Global signatures of protein and mRNA expression levels. Mol Biosyst 5: 1512-1526, 2009.

FUJITA T, YOKOTA S, SAWADA M, MAJIMA M, OHTANI Y, KUMAGAI Y: Effect of MKC-733, a 5-HT receptor partial agonist, on bowel motility and symptoms in subjects with constipation: an exploratory study. J Clin Pharm Ther 30: 611-622, 2005.

GERALD C, ADHAM N, KAO HT, OLSEN MA, LAZ TM, SCHECHTER LE, BARD JA, VAYSSE PJ, HARTIG PR, BRANCHEK TA: The 5-HT4 receptor: molecular cloning and pharmacological characterization of two splice variants. EMBO J 14: 2806-2815, 1995.

GERSHON MD, TACK J: The serotonin signaling system: from basic understanding to drug development for functional GI disorders. Gastroenterology 132: 397-414, 2007.

GLATZLE J, STERNINI C, ROBIN C, ZITTEL TT, WONG H, REEVE JJ, RAYBOULD HE: Expression of 5-HT3 receptors in the rat gastrointestinal tract. Gastroenterology 123: 217-226, 2002. 
GOLDHILL J, PORQUET MF, ANGEL I: The response of rat colonic mucosa to 5-hydroxytryptamine in health and following restraint stress. Eur J Pharmacol 353: 289-296, 1998.

HANSEN MB, WITTE AB: The role of serotonin in intestinal luminal sensing and secretion. Acta Physiol (Oxf) 193: 311-323, 2008.

HIRATA T, KETO Y, NAKATA M, TAKEUCHI A, FUNATSU T, AKUZAWA S, SASAMATA M, MIYATA K: Effects of serotonin 5-HT3 receptor antagonists on stress-induced colonic hyperalgesia and diarrhoea in rats: a comparative study with opioid receptor agonists, a muscarinic receptor antagonist and a synthetic polymer. Neurogastroenterol Motil 20: 557-565, 2008.

JULIO-PIEPER M, O'MAHONY CM, CLARKE G, BRAVO JA, DINAN TG, CRYAN JF: Chronic stress-induced alterations in mouse colonic 5-HT and defecation responses are strain dependent. Stress 15: 218-226, 2012.

KARANTANOS T, MARKOUTSAKI T, GAZOULI M, ANAGNOU NP, KARAMANOLIS DG: Current insights in to the pathophysiology of Irritable Bowel Syndrome. Gut Pathog 2: 3, 2010.

KIM DH, CHO YJ, KIM JH, KIM YB, LEE KJ: Stress-induced alterations in mast cell numbers and proteinaseactivated receptor-2 expression of the colon: role of corticotrophin-releasing factor. J Korean Med Sci 25 : 1330-1335, 2010.

KISO T, ITO H, MIYATA K: Effect of ramosetron on short-circuit current response in rat colonic mucosa. Eur $J$ Pharmacol 320: 187-192, 1997.

KONTUREK PC, BRZOZOWSKI T, KONTUREK SJ: Stress and the gut: pathophysiology, clinical consequences, diagnostic approach and treatment options. J Physiol Pharmacol 62: 591-599, 2011.

LARAUCHE M, KIANK C, TACHE Y: Corticotropin releasing factor signaling in colon and ileum: regulation by stress and pathophysiological implications. J Physiol Pharmacol 60 (Suppl 7): 33-46, 2009.

LEE HJ, BAN JY, SEONG YH: Blockade of 5-HT(3) receptor with MDL7222 and Y-25130 reduces hydrogen peroxide-induced neurotoxicity in cultured rat cortical cells. Life Sci 78: 294-300, 2005.

LI YM, LU GM, ZOU XP, LI ZS, PENG GY, FANG DC: Dynamic functional and ultrastructural changes of gastric parietal cells induced by water immersion-restraint stress in rats. World J Gastroenterol 12: 3368-3372, 2006.

LI Y, LI XF, HUA G, XU JD, ZHANG XH, LI LS, FENG XY, ZHANG Y, DUAN ZP, ZHU JX: Colonic submucosal 5-HT(3) receptor-mediated somatostatin-dependent secretoinhibitory pathway is suppressed in waterimmersion restraint stressed rats. Eur J Pharmacol 656: 94-100, 2011.

MANOCHA M, KHAN WI: Serotonin and GI disorders: an update on clinical and experimental studies. Clin Transl Gastroenterol 3: e13, 2012.

NAGAKURA Y, KONTOH A, TOKITA K, TOMOI M, SHIMOMURA K, KADOWAKI M: Combined blockade of 5-HT3- and 5-HT4-serotonin receptors inhibits colonic functions in conscious rats and mice. J Pharmacol Exp Ther 281: 284-290, 1997.

NING Y, ZHU JX, CHAN HC: Regulation of ion transport by 5-hydroxytryptamine in rat colon. Clin Exp Pharmacol Physiol 31: 424-428, 2004.

PRINCE LS, WORKMAN RJ, MARCHASE RB: Rapid endocytosis of the cystic fibrosis transmembrane conductance regulator chloride channel. Proc Natl Acad Sci USA 91: 5192-5196, 1994.

REBER SO: Stress and animal models of inflammatory bowel disease - an update on the role of the hypothalamopituitary-adrenal axis. Psychoneuroendocrinology 37: 1-19, 2012.

SANGER GJ, YOSHIDA M, YAHYAH M, KITAZUMI K: Increased defecation during stress or after 5-hydroxytryptophan: selective inhibition by the 5-HT(4) receptor antagonist, SB-207266. Br J Pharmacol 130: 706-712, 2000.

SODERHOLM JD, PERDUE MH: Stress and gastrointestinal tract. II. Stress and intestinal barrier function. $A m J$ Physiol Gastrointest Liver Physiol 280: G7-G13, 2001.

STENGEL A, TACHE Y: Neuroendocrine control of the gut during stress: corticotropin-releasing factor signaling pathways in the spotlight. Annu Rev Physiol 71: 219-239, 2009.

YANG N, XUE H, GUO H, CHEN X, ZHU JX: Segmental heterogeneity of epithelial ion transport induced by stimulants in rat distal colon. Biol Pharm Bull 29: 1825-1829, 2006. 
YANG N, LIU SM, ZHENG LF, JI T, LI Y, MI XL, XUE H, REN W, XU JD, ZHANG XH, LI LS, ZHANG Y, ZHU JX: Activation of submucosal 5-HT(3) receptors elicits a somatostatin-dependent inhibition of ion secretion in rat colon. Br J Pharmacol 159: 1623-1625, 2010.

YUAN J, ZHOU J, HU Z, JI G, XIE J, WU D: The effects of jatrorrhizine on contractile responses of rat ileum. Eur $J$ Pharmacol 663: 74-79, 2011. 